\title{
Factors controlling phyto- and bacterioplankton in late spring on a salinity gradient in the northern Baltic
}

\author{
R. Lignell*, S. Kaitala*, H. Kuosa \\ Tvärminne Zoological Station, SF-10900 Hanko, Finland
}

\begin{abstract}
Effects of nutrient enrichment $\left(\mathrm{NH}_{4}{ }^{+}, \mathrm{PO}_{4}{ }^{3-}\right)$, sucrose addition and $<100 \mu \mathrm{m}$ prefractionation (removal of large zooplankton) on phyto- and bacterioplankton were studied from 1985 to 1991 after the peaks of the vernal bloom off the SW coast of Finland. Three day experiments were performed in $100 \mathrm{l}$ transparent plastic enclosures and followed a complete $2^{3}$ factorial design. Phytoplankton productivity (" $\mathrm{C}$ incorporation) and biomass ( $\mathrm{chl}$ a) were P-limited in a fjord-like inlet with low salinity, whereas in the open sea, significant responses were oblained only with the addition of both $N$ and $P$. The dominant algal species accounted for the major part of the community response to nutrient enrichment, which suggests that these results can be extrapolated to the prevailing natural conditions. In late spring, a substantial increase in bacterial productivity ( ${ }^{3} \mathrm{H}$-thymidine method) took place only with the addition of both sucrose and the nutrients that limited algal growth. No clear responses were observed in the bacterial biomass, which indicates strong control by grazers or viruses.
\end{abstract}

\section{INTRODUCTION}

Phyto- and bacterioplankton form the basis of pelagic food webs. The primary production of large (>5 $\mathrm{\mu m}$ ) phytoplankters fuels higher trophic levels directly via the grazing food chain, while the production of small $(<5 \mu \mathrm{m})$ algae is channelled less efficiently via the microbial loop (Sherr \& Sherr 1988). Bacterioplankton use the dissolved and dead particulate organic matter lost directly from the algal community or during grazing and return this organic pool in a useful form to the food web via either the microbial loop (Azam et al. 1983) or the detritus food chain (Fenchel \& Jorgensen 1977). Thus, information on the factors controlling algal and bacterial communities is of vital importance in understanding the functioning of pelagic ecosystems.

These factors can be studied on the basis of passive data obtained by monitoring the system or active experiments in which the responses of the planktonic

\footnotetext{
- Present address: University of Helsinki, Department of Limnology, SF-00710 Helsinki, Finland
}

community to appropriate manipulations are followed. Complex and dynamic interactions in the natural community and autocorrelation in the data make the interpretation of monitoring results difficult, even when the data allow a formally correct statistical treatment. Thus, we have chosen active experimentation with a complete factorial design. The resulting empirically fitted response surfaces have then been studied to reveal the major single and combined effects of the treatments (Box \& Draper 1987).

Since the mid 1980s, we have conducted factorial experiments in late spring in the northern Baltic. We find this period ecologically interesting, as it represents a transition stage between the spring bloom based mainly on new production (sensu Dugdale \& Goering 1967) and the summer minimum period based mainly on regenerated production, and hence it starts a new page in the functioning of the pelagic ecosystem.

Three treatments were used. (1) Nutrient enrichment. Lakes are generally considered P-limited and oceans N-limited (e.g. Hecky \& Kilham 1988), and we tested the applicability of this scenario to the northern 
Baltic at 2 sites on a salinity gradient formed by mixing of inflowing freshwater and Baltic surface water. (2) Removal of large zooplankton by $<100 \mu \mathrm{m}$ prefractionation. Phytoplankton may be controlled from above by zooplankton (Hagström \& Larsson 1984, Thingstad \& Sakshaug 1990), and bacteria may also be indirectly affected via enhanced substrate supply during 'sloppy' feeding by zooplankton (Riemann et al. 1986) or due to changes in grazing pressure caused by changes in the structure of the food web (cf. Thingstad \& Sakshaug 1990). (3) Sucrose addition. Bacteria may be substrate-limited (Scavia \& Laird 1987), and also algae may indirectly be affected via increased competition for mineral nutrients by bacteria (Parsons et al. 1981).

\section{MATERIAL AND METHODS}

From 1985 to 1991 , the factors controlling phyto- and bacterioplankton after the peak of vernal bloom were studied off the SW coast of Finland (total of 8 experiments). Three typical examples of the results from late spring are presented here in detail (see Table 2): 2 experiments (in 1989 and 1991) at Lăngskär station in the outer sea zone of the Tvärminne archipelago, and one (in 1990) at Sällvik station in the narrow, ca $15 \mathrm{~km}$ long Pojo Firth where the mixing of inflowing freshwater and Baltic surface water forms a strong salinity gradient (Fig. 1).

The Långskär station is ca $40 \mathrm{~m}$ deep. The area is virtually unaffected by large sewage outlets, and is characterized by occasional inflows of low-salinity surface water from the inner archipelago or of cold, more saline Baltic deep water originating from upwellings. The Pojo inlet resembles a shallow fjord with a maximum depth of $40 \mathrm{~m}$ at Sällvik station, and it is separated from the inner archipelago zone by a shallow $(<2$ to $5 \mathrm{~m}$ ) sill. The Sällvik area receives the main body of its water from eutrophicated Lake Lojo and it is also affected by rural runoff. For a detailed description of the hydrography and the ecology of phyto-and bacterioplankton in the study area see Niemi (1973), Väätänen (1982), Lignell (1990), Kuosa (1991) and the references therein.

In the evening preceding the experiments, water was sampled from the surface. Continuous sampling over ca 20 min from a freely floating boat allowed us to cover small-scale (a few $100 \mathrm{~m}$ ) patchiness in the horizontal distribution of plankton. The water was transferred to ten 100 l transparent plastic enclosures that were mounted in line in a wooden rack, floating outside Tvärminne Zoological Station. The enclosures at the 2 ends of the rack were not used for the experiments; this ensured even light conditions for the 8 experimental units.

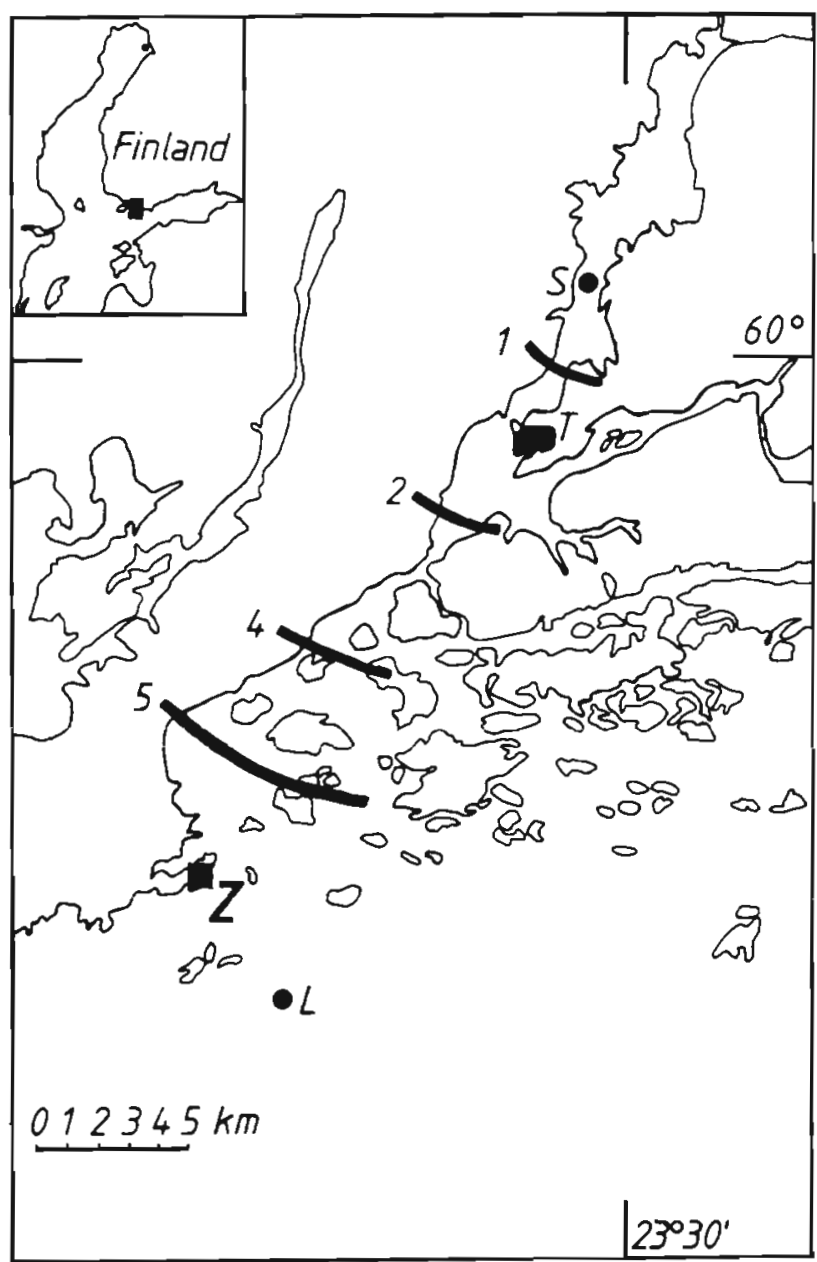

Fig. 1. Study area in the Tvärminne archipelago, northern Baltic. Thick solid lines denote the approximate zones of salinity (\%) on a gradient formed by mixing of inflowing freshwater and Baltic surface water in spring. L: Långskär, S: Sällvik; Z: Tvärminne Zoological Station, T: Tammisaari

Experiments lasted for $3 \mathrm{~d}$ and followed a $2^{3}$ factorial design: all combinations of 3 treatments or factors were done at 2 levels (treatment performed or not, altogether 8 experimental units; Table 1). The treatments were nutrient enrichment $\left(15 \mu \mathrm{g} \mathrm{PO}_{4}{ }^{3-}-\mathrm{Pl}^{-1} \mathrm{~d}^{-1}\right.$ and $\left.60 \mu \mathrm{g} \mathrm{NH}_{4}^{+}-\mathrm{N}^{-1} \mathrm{~d}^{-1}\right)$, addition of sucrose $(60 \mu \mathrm{g}$ sucrose-C $\mathrm{l}^{-1} \mathrm{~d}^{-1}$ ), and prefractionation through a $100 \mu \mathrm{m}$ sieve (most crustaceans and rotifers were retained on the sieve). In 1989, the combined addition of $\mathrm{N}$ and $\mathrm{P}$, addition of sucrose, and $<100 \mu \mathrm{m}$ prefractionation were used as treatments, while in 1990 and 1991 the effects of $\mathrm{N}$ and $\mathrm{P}$ were tested separately along with sucrose. The factors studied in earlier experiments were either the same as in 1989 (in 1986 and 1988) or the same as in 1990 and 1991 (in 1985 and 1987). Each experimental unit was sampled daily (Days 0 to 3 ) at about 09:00 h, then N, P, and sucrose 
Table 1 Complete $2^{3}$ factorial design of experiments in 1990 and 1991 Surface samples in floating 1001 enclosures received additions of $\mathrm{NH}_{4}{ }^{+}-\mathrm{N}, \mathrm{PO}_{4}{ }^{3-}-\mathrm{P}$ and sucrose-C (all in $\mu \mathrm{g} \mathrm{l}^{-1} \mathrm{~d}^{-1}$ ). In 1989, prefractionation through a $100 \mu \mathrm{m}$ sieve was used as a treatment along with addition of sucrose and combined addition of $\mathrm{N}$ and $\mathrm{P}$

\begin{tabular}{|c|c|c|c|}
\hline \multirow[t]{2}{*}{ Unit } & \multicolumn{3}{|c|}{ Treatments } \\
\hline & $\mathrm{NH}_{4}^{+}$ & $\mathrm{PO}_{4}^{3-}$ & Sucrose \\
\hline 1 & 0 & 0 & 0 \\
\hline 2 & 60 & 0 & 0 \\
\hline 3 & 0 & 15 & 0 \\
\hline 4 & 60 & 15 & 0 \\
\hline 5 & 0 & 0 & 60 \\
\hline 6 & 60 & 0 & 60 \\
\hline 7 & 0 & 15 & 60 \\
\hline 8 & 60 & 15 & 60 \\
\hline
\end{tabular}

were added, and finally all enclosures were thoroughly mixed. All in situ incubations were started within $1 \mathrm{~h}$ of sampling.

Measurements. Phytoplankton primary productivity was measured by the ${ }^{14} \mathrm{C}$ method (Steemann Nielsen 1952). $\mathrm{NaH}^{14} \mathrm{CO}_{3}$ at $1 \mu \mathrm{Ci}$ (specific activity of the undiluted stock was $57.8 \mathrm{mCi} \mathrm{mmol}^{-1}$; Amersham, UK) was added to precombusted $20 \mathrm{ml}$ glass scintillation vials. Duplicate light vials from each experimental unit and duplicate dark vials from Units 1 and 8 (Table 1) were incubated at $1 \mathrm{~m}$ depth for $4 \mathrm{~h}$.

Primary productivity (particulate plus dissolved organic ${ }^{14} \mathrm{C}$ ) was measured by allowing an acidified $4 \mathrm{ml}$ subsample $(\mathrm{pH}<2)$ to stand in an uncapped glass scintillation vial for $24 \mathrm{~h}$ (no bubbling), before LumaGel scintillation cocktail (Lumac, The Netherlands) was added (Niemi et al. 1983). All radioactivity measurements were made with a LKB Rackbeta 1215 liquid scintillation counter (LKB-Wallac, Finland), using the external standard channel ratio method. For ${ }^{14} \mathrm{C}$ primary productivity calculations, the mean of the dark values in Units 1 and 8 (no quantitatively important differences were observed) was subtracted from the light values. Dissolved inorganic carbon was measured with an infra-red carbon detector (Elektro-Dynamo carbon analyzer, Laitila, Finland).

Algae were determined at the beginning and end of each experiment (on Days 0 \& 3) on acid Lugolpreserved samples by the method presented by Utermöhl (1958), using phase contrast microscopy (Leitz Diavert, Germany). The nomenclature follows Edler et al. (1984) with some exceptions.

Chlorophyll a was measured daily with a SequiaTurner 450 fluorometer (calibrated with pure chl a), using Whatman GF/F filters and $24 \mathrm{~h}$ ethanol extraction. No corrections were made for phaeopigments.

Bacterial secondary productivity was measured from tritiated thymidine incorporation (TTI) into material precipitable with cold trichloroacetic acid (TCA) (Fuhrman \& Azam 1982). A saturating (10 nmol) concentration of ${ }^{3} \mathrm{H}$-thymidine (specific activity 38 to $44 \mathrm{Ci}$ $\mathrm{mmol}^{-1}$; Amersham) was added to $20 \mathrm{ml}$ glass scintillation vials (duplicate light samples and 1 formalin-killed blank from each unit). TTI incubations were conducted at $1 \mathrm{~m}$ depth; they were started simultaneously with the ${ }^{14} \mathrm{C}$ incubations, and after $1 \mathrm{~h}$ were terminated with formalin $(200 \mu \mathrm{l} 38 \%$ formalin to $20 \mathrm{ml})$. Subsamples $(5 \mathrm{ml})$ were extracted for 0.5 to $1 \mathrm{~h}$ with $5 \mathrm{ml} 10 \%$ TCA in icecold conditions and then filtered on $0.2 \mu \mathrm{m}$ cellulose acetate filters (Sartorius). Filters were rinsed with $5 \%$ ice-cold TCA before the addition of LumaGel scintillation cocktail and subsequent radioactivity measurements (LKB Rackbeta 1215 liquid scintillation counter).

For the enumeration of bacterial cells, bacteria were stained with acridine orange (Hobbie et al. 1977) and counted with a Leitz Dialux epifluorescence microscope. Bacterial biomass was calculated using the average bacterial cell volumes of $0.063 \mu^{3}$ found in spring in our study area (Kuparinen 1988), and a

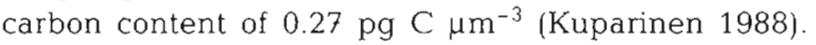
Net bacterial productivity was calculated using a ${ }^{3} \mathrm{H}-$ thymidine conversion factor of $1.1 \times 10^{18} \mathrm{cells} \mathrm{mol}^{-1}$ (Riemann et al. 1987).

Statistical analysis. Experiments followed a complete $2^{3}$ factorial design (Table 1). This allowed us to construct a regression model for each measured variable, in which all single and combined effects of the 3 treatments were included (altogether 7 regression coefficients plus the mean of the responses; Box \& Draper 1987).

Enclosures were sampled 4 times at uniform (1 d) intervals, which resulted in a $4 \times 2^{3}$ experimental design. This allowed the effect of each treatment to be represented by its mean and 3 orthogonal polynomials of degree 1 to 3 , describing the effect over time: that of degree 1 is the best-fitting linear regression for the temporal effect of the treatment ${ }_{i}$ that of degree 2 is the improvement in fit achieved by including the quadratic temporal term, etc. (Rowell \& Walters 1976; for details in introducing polynomials of a degree higher than 1 into the regression model see Draper \& Smith 1981). Thus, altogether 31 orthogonal regression coefficients (plus the mean of the responses) are obtained for the model.

Due to the orthogonality of the experimental matrix (cf. Table 1) the regression coefficients are independent. This allows us to determine the major effects by plotting the corrected contrasts of the regression coefficients (i.e. regression coefficients rescaled to a common variance; Box \& Draper 1987) on a normal probability plot. Those corrected contrasts that follow normal distribution (i.e. the corresponding effects are 


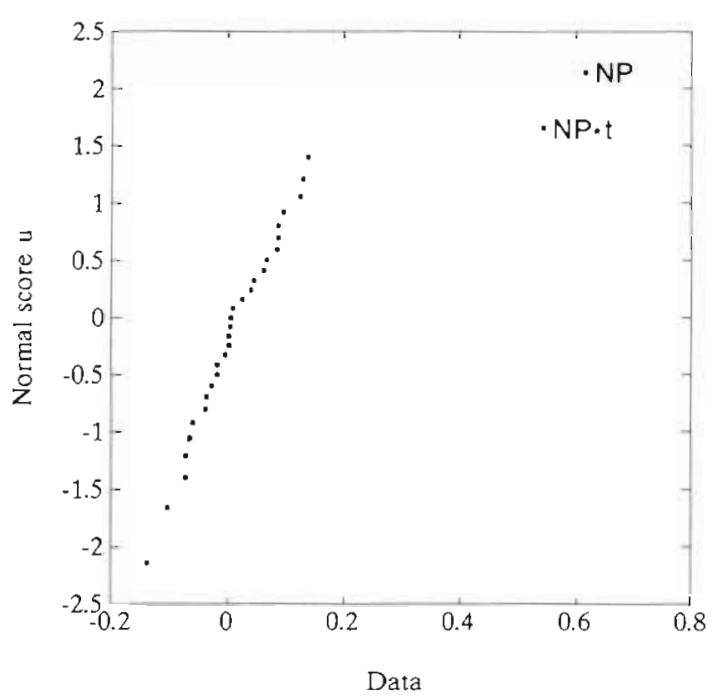

Fig. 2. Normal probability plot of corrected contrasts (standardized regression coefficients) of the regression model. Contrasts that follow normal distribution (corresponding to small treatment effects) form a straight line, while major effects deviate from this line; in this example of primary productivity, in 1989, the single and linear temporal effects of $\mathrm{N}+\mathrm{P}$ enrichment (NP and NP-t, respectively) were important. The probability distribution of the corrected contrasts (vertical axis) is presented in units of standard deviation ( $u$; e.g. $-1<\mathrm{u}<1$ comprises ca $68 \%$ of the data)

small) form a straight line on the normal probability plot, while those contrasts that deviate from this line represent a major manipulation effect (Fig. 2) (Daniel 1959, Montgomery 1984, Box \& Draper 1987). In borderline cases those corrected contrasts were disregarded whose contribution to the information and the adequacy of the regression model was small (also a diagnostic check was applied to the residuals; Montgomery 1984). The resulting response surfaces were then examined to reveal the key factors controlling the phyto- and bacterioplankton communities (Box \& Draper 1987)

\section{RESULTS}

The 3 examples of our manipulation experiments presented here in detail took place during the transition stage between the spring bloom and summer minimum periods of phytoplankton succession in the Tvärminne area (Table 2). In 1989 and 1991, the euphotic layer was already separated from deeper water by a thermocline (both ca $10 \mathrm{~m}$ deep) in the outer sea zone (Långskär station) The vernal phytoplankton. bloom had exploited the mineral nutrients that had accumulated in the water column during the previous fall and winter, so that the nutrient concentrations in the mixed layer were low (1 to $2 \mu \mathrm{g} \mathrm{PO}{ }_{4}{ }^{3-} \mathrm{P} \mathrm{l}^{-1}, 8$ to $9 \mu \mathrm{g} \mathrm{NH}_{4}{ }^{+} \mathrm{N} \mathrm{l}^{-1},<2 \mu \mathrm{g} \mathrm{NO}_{3}^{-}-\mathrm{N} \mathrm{l}^{-1}$ ). In 1990, a $4 \mathrm{~m}$ deep surface layer was separated from the deeper water column by a strong pycnocline formed by temperature and salinity gradients (from 13 to $7^{\circ} \mathrm{C}$ and 0.3 to $4 \%$ ) in the Pojo Firth (Sällvik station). Due to high turbidity, the euphotic layer was only about $3 \mathrm{~m}$ deep. Phosphate and ammonium were found in low

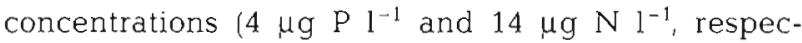
tively), but due to large inputs via inflowing freshwater and runoff from the land, the nitrate concentration was very high $\left(440 \mu \mathrm{g} \mathrm{N}^{-1}\right)$.

In 1989, the dominant species in the phytoplankton community at Langskär station were typical of the spring bloom, the dinoflagellate Peridiniella (syn. Gonyaulax) catenata (Levander) Dodge and the diatom Thalassiosira baltica (Grunow) Ostenfeld, while the subdominant species were characteristic of the late (declining) spring bloom and early summer (Skeletonema costatum Greville and small flagellates; Fig. 3). In 1991, $P$. catenata predominated, and the subdominants were $S$. costatum and a typical member of the early summer algal community, Pseudopedinella elastica Skuja.

In 1990, the phytoplankton community at Sällvik station consisted chiefly of the diatoms Asterionella formosa Hassall and Diatoma elongatum (Lyngbye) C. A. Agardh, which are typical components of the coastal spring bloom in diluted brackish water (Fig. 3). The bacterial numbers were considerably higher in Sällvik than in the outer sea zone, but this was not associated with correspondingly higher net bacterial productivity (Table 2).

\section{Effects of treatments}

Phytoplankton

Phytoplankton primary productivity was limited by the availability of nutrients: in the samples from the low-salinity Pojo Firth, addition of $P$ caused a significant increase in primary productivity, while in the samples from the outer sea zone, combined addition of $\mathrm{N}$ and $\mathrm{P}$ was necessary to evoke a significant response (Fig. 4). The same was true with algal biomass (chl a), but as expected, the effects were somewhat damped and delayed (Fig. 4). In agreement with these results, phytoplankton primary productivity and chl a values in the open sea zone showed $N+P$ limitation in springs 1985 and 1987 as well.

In 1991, nutrient enrichment did not have any major effects on the chl a values within $3 d$, but after $6 \mathrm{~d}$ these values showed a significant increase in the enclosures to which both $\mathrm{N}$ and $\mathrm{P}$ had been added (corresponding regression model estimated on $3 \times 2^{3}$ design, using 
Table 2. Initial (Day 0) conditions in manipulation experiments in late spring 1989-1991 on a salinity gradient off the SW coast of Finland. T: temperature; Sal.: salinity; $\mathrm{N}: \mathrm{P}: \mathrm{NH}_{4}{ }^{+}-\mathrm{N}: \mathrm{PO}_{4}{ }^{3-} \mathrm{P}$ ratio; Chl a: chlorophyll $a_{;}$PPR: ${ }^{14} \mathrm{C}$ primary productivity; BPR: bacterial productivity measured by ${ }^{3} \mathrm{H}$-thymidine incorporation method

\begin{tabular}{|c|c|c|c|c|c|c|c|c|c|c|}
\hline \multirow[t]{2}{*}{ Date } & \multirow{2}{*}{ Site } & \multirow{2}{*}{$\begin{array}{c}\mathrm{T} \\
\left({ }^{\circ} \mathrm{C}\right)\end{array}$} & \multirow{2}{*}{$\begin{array}{l}\text { Sal. } \\
(\%)\end{array}$} & \multirow{2}{*}{$\begin{array}{c}N: P \\
(w t / w t)\end{array}$} & \multicolumn{3}{|c|}{ Phytoplankton } & \multicolumn{3}{|c|}{ Bacterioplankton } \\
\hline & & & & & $\begin{array}{l}\text { Biomass } \\
\left(\mu \mathrm{g} \mathrm{C}^{-1}\right)\end{array}$ & $\begin{array}{l}\text { Chl a } \\
\left(\mu \mathrm{g} \mathrm{l}^{-1}\right)\end{array}$ & $\begin{array}{c}\mathrm{PPR} \\
\left(\mu \mathrm{g} \mathrm{Cl}^{-1} \mathrm{~h}^{-1}\right)\end{array}$ & $\begin{array}{c}\text { No. } \\
\left(\times 10^{6} \mathrm{ml}^{-1}\right)\end{array}$ & $\begin{array}{l}\text { Biomass } \\
\left(\mu \mathrm{g} C 1^{-1}\right)\end{array}$ & $\begin{array}{c}\text { BPR } \\
\left(\mu \mathrm{g} \mathrm{Cl} l^{-1} \mathrm{~h}^{-1}\right)\end{array}$ \\
\hline 16 May 1989 & Långskär & 8.5 & 5.4 & 5.3 & 150 & 5.6 & 18.2 & 2.9 & 49 & 0.43 \\
\hline 8 May 1990 & Sällvik & 8.4 & 0.3 & $3.7^{\circ}$ & 320 & 4.2 & 6.0 & 10.9 & 185 & 0.30 \\
\hline 20 May 1991 & Långskär & 8.1 & 5.9 & 6.8 & 194 & 3.0 & 4.8 & 2.9 & 49 & 0.28 \\
\hline
\end{tabular}

values from Days 0, 3 \& 6; Fig. 4). This delay in biomass response was most likely due to the prevailing cold and rainy period which led to low irradiation and a decrease of $2{ }^{\circ} \mathrm{C}$ in the water temperature at the beginning of the experiment.

Addition of sucrose and $<100 \mu \mathrm{m}$ prefractionation did not have any major effect on phytoplankton productivity or chl $a$, and hence the results from enclosures with these treatments were treated as controls (Fig. 4). The latter result was supported by microscopy, which showed that larger zooplankton were scarce in the experimental units (data not shown).

The temporal course of chl $a$ in the control enclosures consistently showed a decreasing trend during the $3 \mathrm{~d}$ experiments (Fig. 4). This was mainly due to sedimentation of large diatoms and dinoflagellates (Fig. 3). On the other hand, the chain-forming diatom Skeletonema costatum and small flagellated algae (e.g. Pedinella tricostata Rouchijajnen and Pseudopedinella elastica) were at times able to increase their biomass in the control units as well. Generally, the dominant algal species accounted for virtually the whole of the quantitative response of the algal community to nutrient enrichment (Figs. 3 \& 4). In 1991, however, the cold-water spring bloom dinoflagellate Peridiniella catenata did not show any response and was unsuccessful in competition with the flagellate $P$. elastica, both in the control units and in the units with $N+P$ enrichment (Fig. 3). In 1991, a significant response in chl a was observed only after 6 d (Fig. 4), being mainly caused by $P$. elastica ( $72 \%$ of total biomass), while $S$ costatum (6\% of total biomass) and small flagellates were subdominant.

\section{Bacterioplankton}

Nutrient additions led to a moderate increase in bacterial productivity, and in 1989 this also occurred with addition of sucrose (Fig. 4). The combined addition of sucrose and those nutrients that limited phytoplankton primary productivity was necessary.
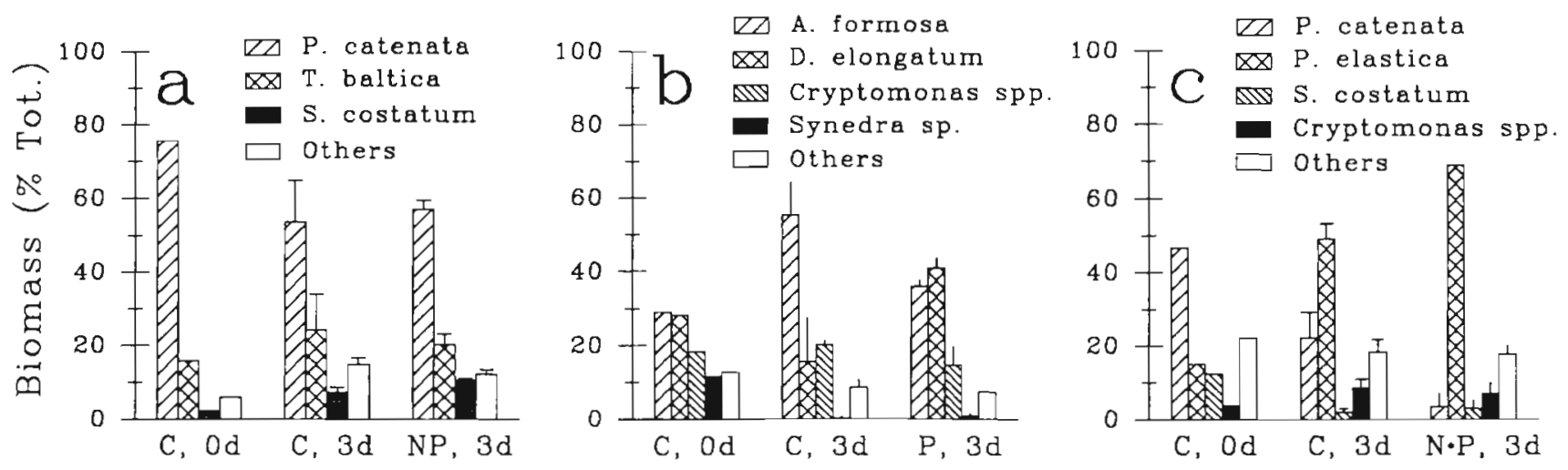

Treatment, Exp. day

Fig. 3. Average development of phytoplankton biomass in controls (C) and in enclosures with major nutrient effects in $3 \mathrm{~d}$ manipulation experiments in (a) 1989, (b) 1990 and (c) $1991 \mathrm{~N}$ and $\mathrm{P}$ additions (both in $\mathrm{l}^{-1} \mathrm{~d}^{-1}$ ): $\mathrm{NH}_{4}{ }^{+}(60 \mu \mathrm{g} \mathrm{N})$ and $\mathrm{PO}_{3}{ }^{3-}$ $(15 \mu \mathrm{g}$ P), respectively. NP: combined addition of N and P. Error bars with and without caps: standard error of the mean (SE; at $95 \%$ confidence interval; 4 to 6 enclosures) and range (2 enclosures) respectively; no error bars (Day 0): results from control Unit 1 (cf. Table 1). (•): a major combined effect (e.g. N.P) 


$\begin{array}{ccc}1989 & 1990 & 1991 \\ \text { Làngskär } & \text { Sällvik } & \text { Làngskär } \\ \text { NP, S, F } & \text { N, P, S } & \text { N, P, S }\end{array}$
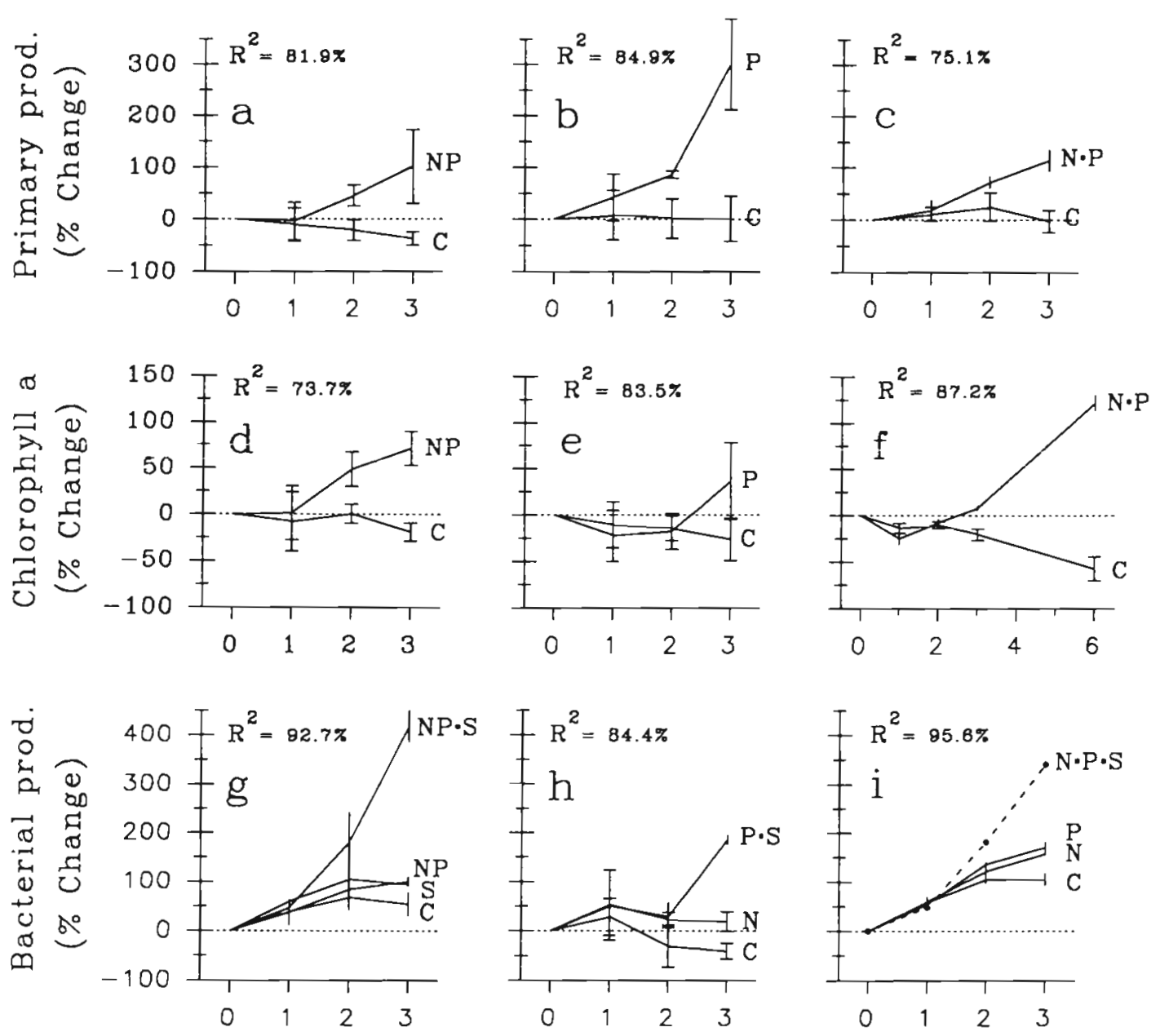

Experiment day

Fig. 4. Effect of nutrient enrichment, sucrose addition and $<100 \mu \mathrm{m}$ prefractionation $(\mathrm{F})$ on phytoplankton primary productivity, chl $a$ and bacterial secondary productivity in late spring 1989 to 1991 . S: sucrose addition $\left(60 \mu \mathrm{C} \mathrm{Cl}^{-1} \mathrm{~d}^{-1}\right)$; other treatment concentrations same as in Fig. 3. Major effects of treatments were revealed by orthogonal regression analysis $\left(\mathrm{R}^{2}=\right.$ adequacy of the regression model), and are presented as mean \% change (vs Day 0 ) in those enclosures where the treatment or combination of treatments caused a major response. $\mathrm{C}$ : Control, mean $\%$ change in enclosures with no major response; $(\cdot)$ : a major combined

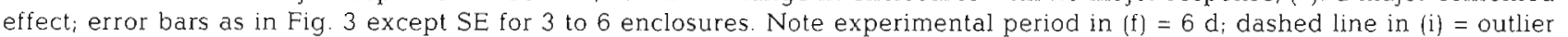

(Day 3) not covered by the regression model

however, for a substantial increase in bacterial productivity (Fig. 4). This was also observed in 1991, although the regression model was unable to cover the steep increase in bacterial productivity at the end of the experiment the result from Day 3 in the unit with the combined addition of N, P and sucrose was an outlier in residual examinations). Delay in the response of the bacterial community in 1991 was at least in part due to the decrease of $2^{\circ} \mathrm{C}$ in the water temperature at the beginning of the experiment.
In spring 1988 , the results were similar to those from 1989 to 1991 . When the experiments were conducted closer to the spring bloom peak in the open sea zone (from 1985 to 1987), however, the combined addition of $N$ and $P$ caused a major increase in bacterial productivity, whereas the single and combined effects of sucrose were mostly small.

Treatments did not have any clear effects on bacterial biomass, and hence these results are presented as the mean change (Day 3 vs Day 0) in all 8 enclosures 


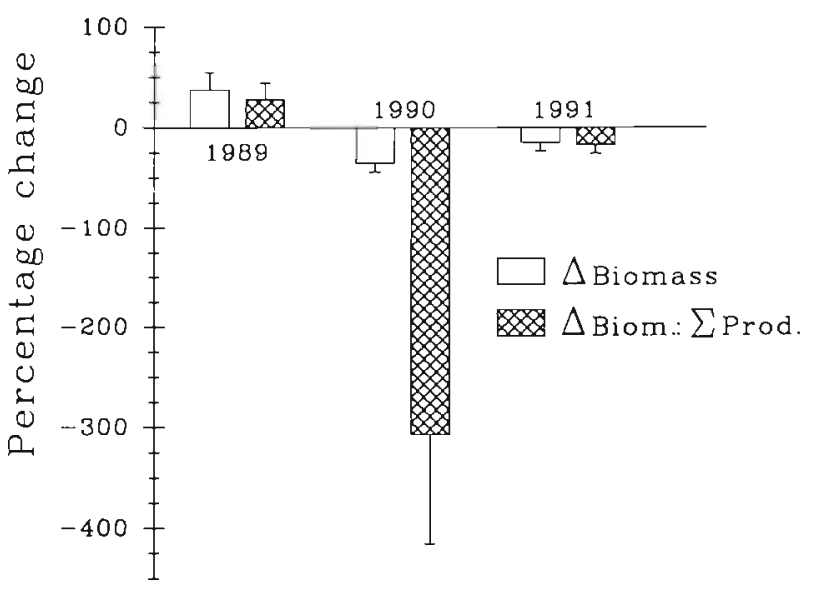

Fig. 5. Average change in bacterial biomass (Day 3 vs Day 0) and the ratio of the average biomass change to integral bacterial production over $3 \mathrm{~d}$ in manipulation experiments from 1989 to 1991. Error bars $=\mathrm{SE}$

(Fig. 5). The mean change in bacterial biomass during the $3 \mathrm{~d}$ experiments, from 1989 to 1991, varied between -35 and $37 \%$ (Fig. 5). The ratio of the mean change in bacterial biomass to the integral bacterial production over $3 \mathrm{~d}$ attained a large negative value with the samples from the low-salinity Pojo Firth compared to those from the open sea (Fig. 5).

\section{DISCUSSION}

\section{Factors controlling phytoplankton}

In samples from the low-salinity Pojo Firth, the phytoplankton community appeared to be P-limited (Fig. 4) Phytoplankton cells are capable of storing nutrients, and our experimental design was unable to resolve the contribution of free external nutrients relative to that of internal reserves (cf. Andersen et al. 1991). Thus, the significant response of phytoplankton to $\mathrm{P}$ addition in Pojo Firth may actually have reflected large internal $N$ reserves of algae. However, while the internal $P$ reserves may comprise a considerable fraction of total algal $\mathrm{P}$, the storage capacity of algae for $\mathrm{N}$ seems to be small (see Andersen et al. 1991). These considerations along with the high mineral N:P ratio in Pojo Firth (Table 2) strongly suggest that our results reflected true P-limitation.

In 1991, the addition of both $\mathrm{N}$ and $\mathrm{P}$ was necessary to evoke a significant response in primary productivity and algal biomass in the samples from the open sea zone (Fig, 4). Similar results were obtained in 1985 and 1987, or whenever the effect of $N$ and $P$ was tested separately. Our results agree with those of Sakshaug \& Olsen (1986), who found that the phytoplankton community was P-limited in brackish fjord waters (formed by mixing of freshwater and North Sea surface water), while off the fjord algal growth was nearly balanced with respect to $\mathrm{N}$ and $\mathrm{P}$.

In spring 1989, removal of large zooplankton by $<100 \mu \mathrm{m}$ prefractionation did not have any major effect on the algal community, and similar results were obtained in 1985 and 1988. Microscopy revealed that large zooplankters were scarce in our samples (data not shown). However, despite their consistency, these results must be treated with caution because of the patchy distribution of zooplankton (George 1989).

Parsons et al. (1981) found reduced primary productivity in enclosures with added glucose and they suggested that this was due to increased algal-bacterial competition for nutrients. Their conclusion was supported by the findings of Bratbak \& Thingstad (1985), who showed that bacteria were superior to algae in competition for nutrients in chemostats. In contrast, our results consistently failed to show any major effect of sucrose on phytoplankton, though during the late declining phases of the spring blooms from 1988 to 1991 the relatively large bacterioplankton biomasses ( 25 to $60 \%$ of algal biomass; Table 2, data from 1988 not shown) indicated that the bacterial community was a potentially important competitor for nutrients. Moreover, bacterial turnover rates were low during the $3 \mathrm{~d}$ experiments with similar values in the control unit and the unit with sucrose treatment $(0.04$ to $0.34 \mathrm{~d}^{-1}$; data not shown), which suggests that the mineral nutrients taken up by bacteria would have mainly been incorporated into bacterial cells (and partly via grazing on bacteria into other components of the microbial loop), rather than recycled effectively within the microbial loop for algal use (cf. Sherr \& Sherr 1988). Thus, in late spring, bacteria do not seem. to be as effective competitors for nutrients in our study area as might be expected from their surface-tovolume ratio, which compares favourably with that of algae. Our study was not designed to address this question thoroughly, however, and hence alternative explanations can not be excluded. For example, it is possible that the proportions of the prevailing bacterial communities that were readily able to use sucrose as their source of carbon and energy were too small for the effect of sucrose to show during our $3 \mathrm{~d}$ experimental periods

When a major increase in phytoplankton biomass took place due to nutrient enrichment (experiments from 1987 to 1990), the dominant and subdominant taxa accounted for the greater part of this increase (Fig. 3; data from 1987 and 1988 not shown). When no increase or a clear decrease in biomass was observed within $3 \mathrm{~d}$, this was a consequence of the sedimentation of dominant cold-water spring bloom 
diatoms and dinoflagellates, probably either mainly due to lack of turbulence (early declining phase in 1985 and 1986; data not shown) or due to the phase of the life cycle of the dominant alga (late declining phase in 1991, when at least one common cold-water dinoflagellate, Gymnodinium sp., had already produced resting cysts that are not active). Moreover, in late spring the quantitative importance of picoalgae is small in our study area (Lignell 1990, Kuosa 1991). and hence their potentially important role in this scenario can be disregarded. These considerations strongly suggest that our results from 1987 to 1991 regarding the factors controlling phytoplankton productivity and biomass can be extrapolated to natural conditions.

We did not test whether the phytoplankton community was actually physiologically stressed by nutrient deficiency. Thus, it is difficult to judge whether our results reflected physiological or 'systemic' nutrient limitation (i.e. merely controlling the size of the phytoplankton standing stock and production; cf. Paasche \& Erga 1988). In general, natural phytoplankton communities do not seem to be physiologically limited by the availability of nutrients, even though the ambient concentrations of mineral nutrients may be very low (Goldman et al. 1979). However, the declining phases of large phytoplankton blooms have been shown to be an exception to this (Sakshaug \& Olsen 1986). Accordingly, the physiological factor was probably important in those experiments that were carried out shortly after the peak of the spring bloom, whereas in late spring the response of the algal assemblage probably reflected mainly systemic nutrient limitation. For example, in 1989 the experiment was conducted closer to the vernal bloom peak in the open sea than in 1991 (cf. initial primary productivity values; Table 2 ), and in. 1989, the declining dominant population of the coldwater diatom peridiniella catenata still responded to nutrient enrichment while in 1991, this was not the case (Fig 3)

\section{Factors controlling bacterioplankton}

Bacterial productivity clearly increased in the controls (Fig. 4), probably as a result of enhanced substrate supply from dying algal cells that settled in the enclosures. In the experiments from 1988 to 1991, combined addition of sucrose and those nutrients, limiting algal growth was always necessary, however, for a substantial increase in bacterial productivity to take place (Fig. 4). Our results are parallel to those of Martinussen \& Thingstad (1987), who showed that bacterial growth may simultaneously be limited by $\mathrm{N}$, $P$, and a carbon source
During the declining phase of the vernal blooms, from 1985 to 1987 , experiments conducted in the open sea were closer to the peak of the bloom than the later experiments. The combined addition of $N$ and $P$ caused the most significant increase in bacterial productivity in these experiments, while the single and combined effects of sucrose were mostly small. These results indicate that during the early stages of the collapse of vernal blooms, dying algal cells provided the bacterioplankton with sufficiently labile organic carbon and this carbon pool was then rapidly exhausted from the mixed layer (cf. Pett 1989).

Bacterial biomass changed relatively little during the experiments in proportion both to initial biomass and to integral production during $3 \mathrm{~d}$ (Fig 5). Results from 1990 were an exception, as the decrease in bacterial biomass was large compared to the integral production. This was probably due to a large proportion of bacteria carried in by inflowing freshwater and flushed from the land, which did not thrive in a more saline aquatic environment (cf. Väätänen 1982)

Our results from late spring with relatively little changes in bacterial biomass (Fig. 5) indicate that a tight grazing control of the bacterial community was already established. Microscopy supported this conclusion, showing that the main bacterial grazers (heterotrophic nanoflagellates and small ciliates) were abundant (data not shown). Bacterial grazers are able to respond rapidly to changes in the abundance of their prey (Heinbokel 1978, Fenchel 1982), which explains at least in part why the differences in bacterial growth rates in different units were not reflected in bacterial biomass values. Moreover, the role of viruses may have been important, as viral lysis has been shown to be extremely efficient in controlling bacterial biomass (Heldal \& Bratbak 1991)

\section{Active mesocosm experiments}

Active experiments should follow a complete factorial design (with all combinations of treatments) if the aim is simultaneous estimation of the statistically significant single and combined effects of several factors of interest (cf. Elser et al. 1990). However, these experiments are laborious due to the need for a large number of experimental units, and as a compromise, we did not use replicate units. Although this does not prevent a formally correct statistical analysis of the results (Daniel 1959, Montgomery 1984), it inevitably lowers the precision of the results. In part this problem was circumvented by the fact that each treatment was performed in half (4 out of 8 ) of the units (cf Table 1). In all experiments at least one of the treatments did 
not have any major effects, which allowed the major effects to be represented as a mean of the responses in at least 2 enclosures (with and without the small treatment effect; Fig. 4) (cf. Montgomery 1984; the orthogonal regression model treats the data in an analogous manner).

Active experiments with confinement of the planktonic community have been strongly criticized; mesocosms were considered 'the worst kind of undefined physical and biological models' by Pomeroy \& Wiebe (1988), and according to Smith (1984) what is actually studied in bottle experiments is the limitation of the specific growth rate of the plankton most actively growing in those bottles'. The most serious weaknesses in our enclosure experiments were probably altered turbulence (even though the enclosure water was mixed by waves), lack of natural random nutrient pulses, and elevated average irradiance levels. The overall 'confinement effect' seems to be a shift towards a steadier system with fewer ecological niches. We are not able to judge how seriously these factors affected our results. In general, while the results of nutrient enrichment experiments are well-documented (for a review see Hecky \& Kilham 1988, Elser et al. 1990), the actual mechanisms behind the responses of the complex interactive network of a phytoplankton community are largely unknown (Lane \& Levins 1977). As discussed earlier, however, in late spring those dominant and subdominant algal species that typically thrive during this stage of the annual succession accounted for virtually the entire response of the algal assemblage to nutrient enrichment, supporting our conclusions based on community-level variables (primary productivity and chl a).

In order to minimize the 'confinement effects' experiments lasted for only $3 \mathrm{~d}$. We have found that this time is usually long enough to reveal the responses of algae and bacteria. Treatment levels were chosen to be (1) high enough to cause a distinct response and (2) 'realistic' (i.e. within the range that the organisms may experience in nature). Thus, the source of organic carbon for bacteria (sucrose) was added at a level corresponding to daily primary production (cf. Table 2). We assumed that phytoplankton mainly excrete carbohydrates during the nutrient-limited conditions in late spring (cf. Harris 1978) and the prevailing bacterial community is hence adapted to exploit monomers and dimers like simple sugars originating from bacterial breakage of excreted carbohydrates (cf. Billen 1990). The molecular weight of sucrose is within the range of 300 to $600 \mathrm{Da}$, which comprises the bulk of dissolved organic carbon excreted by phytoplankton in the Tvärminne area (Lignell 1990). Nutrients were added at a level prevailing below the thermocline (and being introduced as random pulses into the mixed layer). Additions were made in the ratio of $\mathrm{N}: \mathrm{P}=4 \cdot 1$ (by weight), the same ratio in which the nutrients are taken up ( $T$. Tamminen pers. comm.).

In 1989 and 1990, our nutrient additions seem to have been at a reasonable level, since after a lag of $1 \mathrm{~d}$ the planktonic community was able to use up those nutrients that were found to limit algal growth (nutrient data not shown). Thus, the nutrient data also supported our conclusions regarding the limiting nutrients. These results accord with our findings that the control of the phytoplankton community by grazers in late spring in the Tvärminne area is weak, as otherwise we would expect the concentrations of mineral nutrients, rather than algal biomass, to increase in enclosures with nutrient enrichment (cf. Thingstad \& Sakshaug 1990).

\section{CONCLUSION}

During the transition stage between the spring bloom and summer minimum periods, the phytoplankton primary productivity and biomass were controlled by the availability of both $\mathrm{N}$ and $\mathrm{P}$ in the surface waters of the open sea off the SW coast of Finland, while in the low-salinity, fjord-like Pojo inlet the algae were P-limited. Bacterial productivity was controlled by the availability of both a labile carbon source and those nutrients that limited phytoplankton growth, but in contrast to algal biomass, bacterial biomass was strictly controlled by grazers or viruses, or both.

Our experiments represented essentially one point in space and time, even though small scale (a few $100 \mathrm{~m}$ ) horizontal patchiness was covered by sampling from a free-floating boat. Thus, considering the complexity and the dynamic nature of the interactions in the planktonic ecosystem and also the patchy distribution of plankton, our results would seem to be of limited general value. However, our results regarding the factors controlling the bacterioand phytoplankton in late spring showed remarkable interannual consistency, lending support to our conclusions.

Acknowledgements. Thanks are due to Drs Tuomo Leppänen, Jorma Kuparinen, Pirjo Kuuppo-Leinikki, Riitta Autio, and Outsa Setälä for their enthusiastic assistance in the field and laboratory. Dr T. Frede Thingstad made valuable comments on the manuscript. The linguistic form of the manuscript was checked by Mrs Anna Damström. This study is a contribution of project PELAG and it was supported by the Academy of Finland 


\section{LITERATURE CITED}

Andersen, T. Schartau, A. K. L., Paasche, E. (1991) Quantifying external and internal nitrogen and phosphorus pools, as well as nitrogen and phosphorus supplied through remineralization, in coastal marine plankton by means of a dilution technique. Mar. Ecol. Prog. Ser. 69 $67-80$

Azam, F., Fenchel, T., Field, J. G., Gray, J. S., Meyer-Reil, L. A. Thingstad, F. (1983). The ecological role of watercolumn microbes in the sea. Mar. Ecol. Prog. Ser 10 $257-263$

Billen, G. (1990). Delayed development of bacterioplankton with respect to phytoplankton: a clue for understanding their trophic relationships. Ergebn. Limnol. 34: 191-201

Box, G. E. P., Draper, N. R. (1987). Empirical model-building and response surfaces. Wiley, New York

Bratbak, G., Thingstad, T. F. (1985). Phytoplankton-bacteria interactions: an apparent paradox? Analysis of a model system with both cornpetition and commensalism. Mar. Ecol. Prog. Ser. 25: 23-30

Daniel, C. (1959). Use of half-normal plots in interpreting factorial two-level expenments. Technometrics 1:311-341

Draper, N. R., Smith, H. (1981). Applied regression analysis. 2nd edn. Wiley, New York

Dugdale, R. C., Goering, J J. (1967). Uptake of new and regenerated forms of nitrogen in primary productivity. Limnol. Oceanogr. 12: 196-206

Edler, L., Hällfors, G., Niemi, A. (1984). A preliminary checklist of the phytoplankton of the Baltic Sea. Acta bot. fenn. 128: $1-26$

Elser, J. J., Marzolf, E. R., Goldman, C. R. (1990). Phosphorus and nitrogen limitation of phytoplankton growth in the freshwaters of North America: a review and critique of experimental enrichments. Can. J. Fish. Aquat. Sci. 47: $1468-1477$

Fenchel, T (1982). Ecology of heterotrophic microflagellates II. Bioenergetics and growth. Mar. Ecol. Prog. Ser. 8: $225-231$

Fenchel, T., Jørgensen, B. B. (1977). Detritus food chains in aquatic ecosystems: the role of bacteria. In: Alexander, $M$. (ed.) Advances in microbial ecology, Vol. 1. Plenum Press, New York, p. 1-58

Fuhrman, J., Azam, F. (1982). Thymidine incorporation as a measure of bacterioplankton production in marine surface waters: evaluation and field results. Mar. Biol, 66: 109-120

George, D. G. (1.989). Zooplankton patchiness in enclosed and unenclosed areas of water. J. Plankton Res. 11. 173-184

Goldman, J. C., McCarthy, J. J., Peavey, D. G. (1979). Growth rate influence on the chemical composition of phytoplankton in oceanic waters. Nature, Lond. 279: 210-215

Hagström, A., Larsson, U. (1984). Diel and seasonal variation in growth rates of pelagic bacteria. In: Hobbie, J. E., Williams, P. J. LeB. (eds.) Heterotrophic activity in the sea. NATO Conf. Ser. 4. Plenum Press, New York, p. 249-262

Harris, G. P. (1978). Photosynthesis, productivity and growth. Ergebn. Limnol. 10: 1-171

Hecky, R. E., Kilham, P. (1988). Nutrient limitation of phytoplankton in freshwater and marine environments: a review of recent evidence on the effects of enrichment. Limnol. Oceanogr. 33: 796-822

Heinbokel, J. F. (1978). Studies on the functional role of tintinnids in the Southern California Bight. I. Grazing and growth rates in laboratory cultures. Mar. Biol. 47: 177-189

Heldal, M., Bratbak, G. (1991). Production and decay of viruses in aquatic environments. Mar. Ecol. Prog. Ser. 72 : $205-212$
Hobbie, J. E., Daley, R. J., Jasper, S. (1977). Use of Nuclepore filters for counting bacteria by fluorescence microscopy. Appl. environ. Microbiol. 33: 1225-1228

Kuosa, H. (1991). Picoplanktonic algae in the northern Baltic Sea: seasonal dynamics and flagellate grazing. Mar. Ecol. Prog. Ser. 73: 269-276

Kuparinen, J. (1988). Development of bacterioplankton during winter and early spring at the entrance to the Gulf of Finland, Baltic Sea. Verh. int. Verein. Limnol. 23: $1869-1878$

Lane, P., Levins, R. (1977). The dynamics of aquatic systems. 2. The effects of nutrient enrichment on model plankton communities. Limnol. Oceanogr. 22: 454-471

Lignell, R. (1990). Excretion of organic carbon by phytoplankton: its relation to algal biomass, primary productivity and bacterial secondary productivity in the Baltic Sea. Mar. Ecol. Prog. Ser. 68: 85-99

Martinussen, I., Thingstad, T. F. (1987). Utilization of N, P and organic $\mathrm{C}$ by heterotrophic bacteria. II. Comparison of experiments and a mathematical model. Mar. Ecol. Prog. Ser. 37: 285-293

Montgomery, D. C. (1984). Design and analysis of experiments. Wiley, New York

Niemi, $\AA$. (1973). Ecology of phytoplankton in the Tvärminne area, SW coast of Finland. I. Dynamics of hydrography, nutrients, chlorophyll a and phytoplankton. Acta bot fenn. 100: 1-68

Niemi, M., Kuparinen, J., Uusi-Rauva, A., Korhonen, K. (1983). Preparation of algal samples for liquid scintillation counting. Hydrobiologia 106: 149-156

Paasche, E., Erga, S. R. (1988). Phosphorus and nitrogen limitation of phytoplankton in the inner Oslofjord (Norway) Sarsia 73: 229-243

Parsons, T R., Albright, L. J., Whitney, F., Wong, C. S., Williams, P. J. LeB. (1981). The effect of glucose on the productivity of seawater: an experimental approach using controlled aquatic ecosystems. Mar. environ. Res. 4 $229-242$

Pett, R. J (1989). Kinetics of microbial mineralization of organic carbon from detrital Skeletonema costatum cells. Mar. Ecol. Prog. Ser. 52: 123-128

Pomeroy, L. R., Wiebe, W. J. (1988). Energetics of microbial food webs. Hydrobiologia 159: 7-18

Riemann, B., Bjørnsen, P. K., Newell, S., Fallon, R. (1987). Calculation of cell production of coastal bacteria based on measured incorporation of ${ }^{3} \mathrm{H}$-thymidine. Limnol. Oceanogr. 32: 471-476

Riemann, B., Jørgensen, N. O. G., Lampert, W., Fuhrman, J A. (1986). Zooplankton induced changes in dissolved free amino acids and production rates of freshwater bacteria. Microb. Ecol. 12: 247-258

Rowell, J. G., Walters, D. E. (1976). Analysing data with repeated observations on each experimental unit. J. agric Sci., Camb. 87: 423-432

Sakshaug, E., Olsen, Y. (1986). Nutrient status of phytoplankton blooms in Norwegian waters and algal strategies for nutrient competition. Can. J. Fish. Aquat. Sci. 43: $389-396$

Scavia, D., Laird, G. A. (1987). Bacterioplankton in Lake Michigan: dynamics, controls, and significance to carbon flux. Limnol. Oceanogr. 32: 1017-1033

Sherr, E., Sherr, B. (1988). Role of microbes in pelagic food webs: a revised concept. Limnol. Oceanogr 33: $1225-122 ?$

Smith, S. V. (1984). Phosphorus versus nitrogen limitation in the marine environment. Limnol. Oceanogr. 29 : $1149-1160$ 
Steemann Nielsen, E. (1952). The use of radioactive carbon $\left({ }^{14} \mathrm{C}\right)$ for measuring organic production in the sea. J. Cons. perm. int. Explor. Mer 18: 117-140

Thingstad, T F., Sakshaug, E. (1990). Control of phytoplankton growth in nutrient recycling ecosystems. Theory and terminology. Mar. Ecol. Prog. Ser. 63: 261-272

This article was submitted to the editor
Utermöhl, H. (1958). Zur Vervollkommung der quantitativen Phytoplanktonmethodik. Mitt. int. Ver. Theor. Angew. Limnol 9: 1-38

Väätänen, P. (1982). Effects of freshwater outflows on microbial populations in the Tvärminne archipelago, southern Finland. Holoarctic Ecol. 5: 61-66

Manuscript first received: February 6, 1992 Revised version accepted: May 25, 1992 